\title{
Local Politics in Indonesia, 1999-2010: A Literature Review ${ }^{1}$
}

\section{Hasrul Hanif \&Pratikno}

\section{Introduction}

Since the resignation of President Suharto in 1998, Indonesia has undergone a massive process of decentralisation and democratisation. Political power no longer concentrates at the national level, but is decentralised in local domains. Furthermore, in the cases of Aceh and Papua, the central government has had to give relatively broader autonomy in those regions in comparison with other regions of Indonesia.

Nowadays, political processes do not unfold in a monolithic manner; rather they are dispersed due to the considerable progress of democratisation in society. Political processes are no longer determined in, and by, Jakarta, the capital city. Furthermore, the current political process represents the role of multiplying actors in which bureaucracy is no longer the only dominant one. Simultaneously, many actors who formally have no authority are, in fact, able to exert their influence on the day-to-day policy process. In short, state power has undergone a breakdown and been dispersed along a centrifugal pattern which creates heterogeneous centres of

The authors express their gratitude to Joash Tapiheru, Hendra Tri A., Ayya Sovya, and Ratna Puspita, who have helped in data collection and writing process of this article. Special thanks is also expressed here to the authors colleagues at the Department of Politics and Government, Faculty of Social and Political Sciences, University of Gadjah Mada, Indonesia, for their studies on regional autonomy and local politics which have contributed and inspired the authors to write this article. Both authors, however, hold the responsibility over the substance of this article. 
power.

Therefore, exploration of the literature on local politics in Indonesia is an interesting and academically rewarding exercise. This paper attempts to map out the existing literature on the post-1999 political landscape at the local level. This literature review is made up by five key questions: (1) How is localising of power in Indonesia understood? (2) How does power operate at local levels? (3) What are the forces that shape Indonesian local politics? (4) What are the prominent manifestations in Indonesian local politics? (5) What are alternative political forces that possibly represent the setting up of the street demonstrations? (6) What is the type of democratic governance format explored in the existing literature?

\section{Localising power in the post-1999 Indonesia}

Indonesia experienced a prolonged history of a centralistic system of government since 1966 until mid 1998, constituting almost two-thirds of Indonesian post-independence political history. This process led to a situation in which the political process at the local level was merely a reflection of what took place at the national level. The state domination of the political process through the nexus of bureaucracy, Golongan Karya (GOLKAR), and the military, characterised the political process both at the national and local levels, even though there was social resistance to the state's domination during this period (see Lay, 2010; Uhlin, 1997). Overall, Indonesian politics under the New Order regime represented a powerhouse state within which a hyper-centralistic, homogenous, and monolithic power relation was obvious (Schillers, 1996).

The fall of Suharto regime in 1998 has opened up a democratic space and thus made possible the fulfilment of decentralisation demands. The short period of the B. J. Habibie presidency issued functional and fiscal decentralisation policies in the spirit of democratisation. The national parliament passed bills_Law No. 22/1999 and Law No. 25/1999, then later revised through Law No. 32/2004 and Law No. 33/2004 - to regulate the local government system and local budget system. The promulgation of this law has 
initiated excessive decentralisation in Indonesia (Crouch, 2010: pp87-126). ${ }^{2}$

These policies have subsequently acknowledged the district level more than the provincial level as a new basis of regional autonomy. Under this new arrangement, district governments whose powers had previously been strictly circumscribed were now to take all responsibility for most basic public services, such as education, health, labour and so forth (Aspinall and Fealy, 2003). In this new decentralised regime, the province has been designed rather as the representative of the national government at the local level, and has focused more on delivering a 'deconcentration' mandate and mediatory roles among autonomous districts (Pratikno, 2005; Wibisono, 2003).

These policies have also enhanced the role and power of the local parliament significantly in comparison to being under the control of the New Order regime. Under the previous centralised regime these local parliament served only as a rubber stamp for decisions made by the bureaucracy. After decentralisation policy was introduced, the local parliament took on a strong role in running a 'checks and balances' mechanism and providing significant authority in the legislation, budgeting, and oversight processes (Lay, 2003). ${ }^{3}$

2 Decentralisation actually is not something alien in the political and governance dynamics in Indonesia. Soetandyo Wignjosoebroto (2005) mentions that the Dutch East Indie Colonial government introduced decentralisation policy through the Decentralisatie Wet 1903 on 23rd July 1903. After the independence, the idea of decentralisation was reintroduced in several laws in various schemes like Law No. 22/1948, Law No. 32/1956, Law No.1/1957, Governmental Decree (Perpu) No. 6/1959, Governmental Decree (Perpu) No. 5/1960, Law No. 5 /1974, Law No. 5/1979 (Kaho, 1988; Kaho, 1982; Lay, 2003; Gaffar, et.al, 2002). However, Afan Gaffar (2000) argued that there were several factors which distinctively characterised the decentralisation policy after 1998 in comparison with its predecessors. Those factors were: (1) democratic and oriented toward democratisation; (2) bringing the government closer to the citizens; (3) broad and effective autonomy; (4) without graded autonomy; (5) no mandate without funding.

3 The new Law No. 32/2004 has caused some significant changes in comparison to the Law No. 22/1999 on the arrangement of regional autonomy and local government. Law No. 22 showed a blatant shift from executive to legislative power. The executive authority at local level was held accountable to the local parliament where the authority to elect and eject local government chief was resided. The Law No. 32/2004 annulled this authority from the local parliament. According to this currently effective law, the local parliament is merely an element of local government instead of a legislative body at the local 
It is hard not to say that the decision to devolve power to the local governance has been a response to growing public demands, ranging from a more equitable share among regions to independence from various parts of Indonesia. At the time of the New Order regime's collapse, the state had exhausted its coercive capacity and suffered a legitimacy crisis partly as result of the economic crisis. This situation made the state incapable of suppressing those demands and, thus, accommodation was the more rational and acceptable option (Pratikno, 2003).

Such a crisis of legitimacy energised massive demands from local actors for gaining wider autonomy and larger resource allocations without any interventions on the part of the central government (Rasyid, 2003). Several naturally resource-rich regions called for a fair fiscal allocation. This 'negotiation' then resulted in the new fiscal decentralisation policy that has since provided bigger fiscal allocations for naturally resource-rich regions, such as Riau, Central Kalimantan, and East Kalimantan provinces. Under this new fiscal arrangement, the central government re-arranged the intergovernmental transfer through the introduction of Dana Alokasi Umum (General Allocation Fund) and Dana Alokasi Khusus (Special Allocation Fund). Furthermore, the central government also rearranged the Dana Bagi Hasil Pajak and Sumberdaya Alam (Tax and Natural Resources-Based Shared Funds), which was very much beneficial for regions with huge reserves of natural resources (Silver, Azis and Schroeder, 2001; Lewis, 2001).

The situation was worse in the case of Papua and Aceh. In the 2000 s, both not only requested for the bigger fiscal allocations but also independence. The people of these provinces were disappointed by prolonged and unjust economic development, and human rights violations (Reid, 2006; Pamungkas, Hanif and Endaryanta, 2010). Such grievance worsened with the emergence of a latent ethnonationalism (Karomba, 2004; Wanimbo, 2003; Hadi et. al., 2006),

level. The local government chief answers to the Minister of Home Affairs and is required only to hand to the local parliament an Appendix of Accountability Report (Laporan Keterangan Pertanggungjawaban - LKPJ) instead of the Accountability Report (Laporan Pertanggungjawaban - LPJ). 
which fuelled the spread of ethnic-based conflicts (Bertrand, 2004).

This situation subsequently prompted the national government to issue a special autonomy policy. Through Law No.21/2001 on Special Autonomy for Papua, the central government assigned special autonomy status, signifying distinct regional autonomy in comparison with other regions in Indonesia. This special autonomy was based more on the province and was characterised by broader recognition toward indigenous symbols, authority, and fiscal and local governance that were distinctively Papuan. For example, the central government formally recognised the existence and authority of the Majelis Rakyat Papua (MRP, or Papuans People Assembly) as an alternative representation arena, complementing the Dewan Perwakilan Rakyat Papua (DPRP, or Papuan People's Representative Council) as the common representative body found in other parts of Indonesia.

The central government implemented a similar arrangement in Aceh. The Government of Indonesia (GoI) and Gerakan Aceh Merdeka (GAM) signed the Helsinki Memorandum of Understanding (MoU) in August 2005, a year after the tsunami that ended the violent conflict. In the following year, the government of Indonesia enacted Law No.11/2006 on the Government of Aceh, serving as the legal basis for the recognition toward the special autonomy status of Aceh. This special autonomy status gave Aceh broader space to express its own pre-existing and distinct symbolic aspects and also broader authority to manage its natural resources.

By upholding the special status, social and political processes in the two provinces had much more dynamics and were thus more unique than those of other provinces (Chauvel, 2010; Tornquist, Prasetyo and Birks, 2010; Basyar, et.al., 2008).

The demand for a widening political arena is also represented by the massive request for pemekaran daerah (redistricting regions). Within the context of decentralisation, Indonesia is now facing many proposals for the redistricting of regions in order to set up new autonomous regions. It is surprising that the number of districts in Indonesia has doubled within a decade. At least 153 new 
186 autonomous regions - either provinces or districts/municipalitywere established from 1999-2006. The establishment of 148 from 153 new autonomous regions took place under the two administrations before Susilo Bambang Yudhoyono took over the presidency. Within this period of seven years, the number of autonomous regions in Indonesia increased to 450 districts/municipalities. There have been eight new provinces since 1998.

The changing character of Indonesian politics is not only presented through the degree of regional autonomy but also in bureaucratic reform. There is also significant bureaucracy reorganisation at the district level. Prior to 2005, the heads of local government were elected by the local parliament. Since then, they have been elected through direct election. During this period, nonmilitary and non-bureaucracy figures have enjoyed increased chances of getting elected as a local chief of government. However, in some cases the bureaucracy and elites from the previous regime have shown an ability to adapt to the new situation and reconsolidate their grip on power and public offices (Malley, 2003; Erb and Sulistyanto, 2009).

The process of bureaucratic re-organization and reform has taken place not only at the level of the local executive but also within whole institutions of state bureaucracy. This process has been characterised not only by the re-orientation and revision of the bureaucracy, but also in the restructuring of these institutions and their functions. This process, however, has not been immune to strong politicisation, which has occurred simultaneously with it becoming more technocratic. The politicisation of bureaucratic reform refers to the various reform activities coloured by considerations of personal political loyalty, ethnic and religious bases, or patronage linkages instead of considerations solely on competence and technocratic capacity (Rohdewohld, 2003; Said, 2005).

Considering those aforementioned changes, local politics now not only emerges as a significant political arena but also becomes a new arena full of contestation among alliances of social interests (Hadiz, 2011). In other words, political expression at the local level turns 
out to be characterised by various contestations and competitions. Thus, it is obvious that a radical polycentric structure has formed at the local level of governance (Harriss, Stokke, Tornquist, 2004). The political dynamics at the local level show not only the existence of diverse patterns of power relations but also further confirms there is no longer a single centre of power.

Distinctive characteristics mark these contestations and competitions. First, there have been attempts from some elements of the previous regime to adapt and organise themselves into the new political structure in order to ensure their control over political and economic resources at local level. Studies on North Sumatera and Yogyakarta (Hadiz, 2003, 2005), and Demos' national survey (Priyono and Subono, 2007:83-103), showed that old predatory interests incubated under the New Order's vast system of patronage have successfully reconstituted themselves within new local regimes in post-Suharto Indonesia by capturing institutions of democracy. Many dominant elites have adapted and monopolised a mixture of democratic procedures and instruments in order to keep their dominance and hegemony in local politics and exclude grass root political participation in public affairs.

Second, the boundaries between formal and informal structures have become blurred. Several studies have showed that there have been inter-penetrations among various actors in the formal and informal political structures in the economic, political, and cultural fields. The study conducted by Santoso and Tirta (2003) in Southern Sulawesi described that many karaeng (a traditional nobility in Makassar) have played significant roles as intermediary actors, helping ordinary people connect to public affairs and political actors in the Golongan Karyaparty. The formal and informal 'inbetween' positions of karaeng have been institutionalised since the colonial period. Something similar has been showed to occur in Bali (Dwipayana and Putra, 2003; Dwipayana, 2004). Local aristocracy and adat villages have strongly influenced not only social relations but also decision making and regulation in local government and even in market activities (see also Rozi, 2009). 


\section{Power in Indonesian local politics}

The literature on Indonesian local politics extensively acknowledges the considerable changes in contemporary Indonesian politics. Firstly, a broadening of the local political arena has occurred. There is no longer a restriction on anyone expressing his/her political preference. In addition, communities are also relatively free to use either parliamentarian or extra-parliamentarian instruments to channel political activism (Pratikno, 2002; Widianingsih, 2006; Antlov, 2009).

Secondly, there has been an improvement in electoral democracy. Indonesians enjoy not only the freedom to establish political parties but also to participate in elections that relatively free from intimidation and terror. Oversight over the electoral process and the agencies involved help maintain their independency and impartiality (Sukma, 2010; Schmidt, 2010).

Third, there has developed a wider space for people participation, and louder voice for government accountability. In particular, space for participation in planning processes is now widely open. Formally, since the promulgation of Law No. 25/2004, society has been able to participate in the Musyawarah Perencanaan Pembangunan, or Musrenbang (Deliberative Development Planning) at the village to district/municipality levels in order to formulate development issues and budget priorities. This participation has also been fostered in regional and national strategic planning. Aspirations can also be expressed to the legislative body through Penjaringan Aspirasi Masyarakat (Jaring Asmara). This mechanism has come into force when politicians have taken their recess period, three to four times annually (Tamrin and Wijiyati, 2006; Bahagijo and Rusdi Tagaroa, 2005).

Fourth, there has been a positive transformation on the process of public service and social welfare deliveries. Many regions have been attempting to enhance the quality of their health and education services. Many districts/municipalities have been giving social insurance to their unprivileged population (World Bank-INDOPOV, 2006; Eko, 2009; Hanif, 2009). 
Such improvements, however, have not necessarily been related to the development of substantive democracy in political processes. Despite wide optimism, several scholars have reminded us that despite the new dynamics and competitive characteristics of local politics throughout Indonesia, these could not automatically be taken as proof of democratic development at the local level. Hadiz (2003b, 2011) has interrupted the optimism of decentralisation proponent by describing how decentralisation may lead to unintended and unexpected consequences.

Nordholt (2004: 47) revealed that despite the seeming discontinuity between the strong, centralised New Order state and the decentralised and fragmented nature of the post-Soeharto era, Indonesian politics has been marked by strong continuitiesof patrimonial patternswhich have their origin in pre-colonial times. Thus, local democracy in practice has remained elitist and has not provided a significant improvement for the inclusion of the demos (Tornquist, 2009, p2). Political elitism now tends to affect local democratic institutions in decentralised Indonesia.

Many political scholars have thus labelled this political elitism as representing a local oligarchy (Robison and Hadiz, 2004), a local shadow state (Hidayat, 2007), a local aristocracy (Dwipayana, 2004; Savirani, 2004; Klinken, 2010), and local 'bossism' (Savirani, 2004). Nationwide studies conducted by Demos from 2003-2005 show that elites have relatively remained determinant actors in local political processes in which the grass root populations only have narrow a space to actively engage. These dominant elites have adapted and manipulated the existing democratic instruments to maintain their economic, political, cultural domination. In order to ensure their interests, these elites mobilise economic and non-economic resources, including social networks, knowledge, and information (Priyono and Subono, 2007).

In some cases, this elitism has been preserved and developed through violent practices. Bandiyah's study (2008) in Banten Province showed how bandits and strongmen, or jawara have been able to co-opt the political process and even secure public offices 
190 through the manipulation of democratic instruments hand-in-hand with intimidation. Wilson (2010) also explained how political parties have affiliated with thugs and, since the New Order era, have been active in conducting terror, intimidation, and violence in the local political process.

Collusion, corruption, and rent seeking have also been integral elements of relations and communications in this political elitism (Hidayat, 2002). For example, Supeno (2009) noted that regional autonomy has been an opportunity for the redistribution of opportunity and broader institutionalisation of corruption to reach even the smallest societal nodes. Through the Dana Alokasi Umum, Dana Alokasi Khusus, dan Dana Bagi Hasil, the agencies at the local level have huge funds in their hands despite a proper control mechanism. The election of local government chiefs have required huge funds, thus providing further reason for corruption and vote buying. At least three patterns of corruption in this decentralisation era could be identified: maladministration and inefficiency; abuse of public funds; budget manipulation due to limited allocation.

Political elitism works both in formal and informal arenas. In 'The State and Illegality in Indonesia', a distinctive book edited by Aspinall and van Klinken (2011), many writers showed interesting symptoms where the state apparatus as the legal-formal actors turned out to be actors who committed illegal practices most extensively. They concluded: "Illegal practices by state officials are not just aberrations of the state, they are the state. Almost invariably, illegality occurs as part of collective, patterned, organised, and collaborative acts, linked to the competition for political power and access to state resources. While obviously excluding many without connections, corrupt behaviour also plays integrative and stabilising functions. Especially, at the lower end of the social ladder, it gets a lot of things done and is often considered legitimate."

Such conditions puts Indonesia as a new model of a shadowstate in which the non-state power predominantly influences, or even determines, formal political processes in local levels. Hidayat's data (2007) on Banten province in the post-Suharto period has recalled 
academic literature on the idea of shadow state. He (2007: p224) noted that: "Decision-making and policy implementation in the regions are now flavoured with 'collusion' and bargaining of interests among the local government, executive elite and the jawara as entrepreneurs. If this empirical reality is related to the shift in patterns of state-society interactions...then the Banten case shows that postSuharto decentralization and regional autonomy has created greater space for societal elites to build and develop informal networks with local state actors. The project racketeering occurred together with a weakness in the formal institutions of local government in Banten... This resembles... a 'Shadow State'."

Sidel (2004) and also Savirani (2004) have emphasised the role of strongmen or mafia in local politics. Based on the experience in Indonesia, Thailand and Philippines, Sidel offered a new framework on the 'local strongman' analysis by noting that the influence of a local boss, the mafia or local clans has been shaped by the opportunities and constraints for accumulation and monopolisation of local economic and political power, as provided by the micro and macro structures of the state. Savirani described three models of local strongmen in Indonesia: the aristocrat model; the businessman model; the politician model. In line with Sidel's argument, Savirani emphasised the emergence of local strongmen due to the strength of the state instead of society.

\section{Prominent political manifestations of local politics}

What are the prominent political manifestations that make political elitism and patronage possible? Much of the literature concludes that political process in Indonesia is highly manifested by the massive mobilisation of identity politics. Indonesian local politics, it has been argued, much more represents the preserving ethnos than the rising of demos. This can be easily identified in the following identity-based political practices.

Ethnic-based politics-including blood heritage, religion, and territory-is extensively mobilised, particularly in regional redistricting and electoral processes (Kocu, 2007; Umasugi, 2009; 
192 Adiyoga, 2003) because ethnicity remains one of the strongest bases of political identification in a society of fragmented social structures. Studies on pemekaran daerah conducted by Aragon (2007), Vel (2007), Roth (2007), and The Asia Foundation (2004) concluded that ethnicity drove popular demands towards the establishment of new autonomous regions in many places. Many social and political organisations that have supported pemekaran daerah believed it would eliminate inter-regional disparities and ineffective public service delivery caused by previous ethnic-biased policies and political discrimination (Hanif and Oktafiani, 2007)

The resurgence and revitalisation of adat institutions in local governance and representation could be viewed as another expression of identity politics (Henley and Davidson, 2007). This revival has not only been directed toward reconstituting symbolic cultural expressions, but has also marked an attempt to reclaim political authority and the authority over the natural resources of these institutions (JPP, 2010). Many regions have re-established their traditional institutions in order to reclaim the traditional authority as expression of their resistance against intervention by the central government, such as in cases in the District of Kutai Kertanegara and the Province of Yogyakarta (Amril, 2002; Maunati, 2004; Eko, 2005; Sumarty, 2007; Tirtosudarmo, 2007; Alqadrie, 2008; Husein and Ramadhan, 2008; Musa, 2008; Pamungkas, 2008; Burns, 2010).

Identity politics does not only operate in the revitalisation of socio-cultural manifestation, but also through the formalisation of primordial identities, particularly religion and ethnicity, in formal public life. An increasing number of Islamic syariah laws (Muhammad, 2003) have been introduced, and adat rules promoted at the local government level (Windia 2008; Burns, 2010). For example, according to Law No.11/2006, Aceh has distinctive authority to enact syariah. Surprisingly, these laws have also been enacted in other parts of Indonesia concerning various issues, ranging from the requirement for women to wear the hijab and the requirement for women to acquire proficiency in Qur'an reading for public office positions. Instead of Mahkamah Syariah (SyariahCourt), several adat organisations have acquired the power to apply formal 
sanctions on those members of a community judged to have violated the traditional rules.

\section{The possibility of new political manifestation in Indonesian local politics}

Although Indonesian local politics has been predominantly characterised by ethnos-oriented politics, many studies on contemporary Indonesian local politics have identified various innovations and breakthroughs in local governance that form the embryo of interest-oriented politics. An increasing number of local governance innovations have, for example, occurred in (a) promoting and achieving good climates for economic development; (b) enhancing participatory planning and budgeting, social audit and government accountability;(c) endorsing open and transparent government; innovating basic public service delivery; and (d) initiating pro-poor regional development or poverty alleviation.

The Jawa Pos Institute of Pro-Autonomy-JPIP (2006) has, by conducting in-depth monitoring and performance evaluation of local governance at the province level in East Java, Central Java, Yogyakarta and East Kalimantan, identified various efforts initiated by local governance to achieve local economic growth, empowerment, and equity. Many regions in Indonesia have shown positive achievements to foster good climates for local economic development by re-organising local bureaucracy, especially concerning permit procedures for investment, improving physical infrastructure, and endorsing competitive local products. They also have initiated much inter-governmental cooperation and management in order to enhance integrated economic growth and share the benefits, burdens, and costs of public service delivery among districts/municipalities (Pratikno, 2007).

In order to institutionalise economic equity and poverty alleviation, many regions also have initiated strategic planning efforts to handle these issues. They have not only promoted participatory poverty assessments (PPA) but also initiated various social assistance and social protection programmes. Moreover, many programmes 
194 of poverty alleviation have been driven by community-based organisation, such as Rukun Tetangga (JPIP, 2006: pp70-76).

Some regions have also attempted to innovate on their public service policies to broaden access of citizen to health and education. Regions including Purbalingga, Solo, and Yogyakarta, have initiated local universal health insurance and special services for elder people, pregnant women, and children. Others, such as Jembrana, Polman, and Tanah Datar, have succeeded in promoting education for all and the improvement of teacher and student welfare (Dwiyanto, 2003; World Bank-INDOPOV, 2006; Sumanto, 2008).

The improvement of participation in local planning and budgeting is another signal of optimism for deepening local democracy. As mentioned earlier, the states have opened space for social participation in development planning. Thus, many civil society organisations have tried to enhance participatory budgeting and planning in many regions in Indonesia. To a varying degree and extent, they have also endorsed governance accountability by enhancing social engagement in policy monitoring (Tamrin and Wijiyanti, 2006; Husna and Sujito, 2009).

The promulgation of Law No. 14/2008 on Freedom of Information (Keterbukaan Informasi Publik) also has contributed to the reform of public information management, enabling broader segments of society to access information. This, in turn, has enhanced the capacity to hold the bureaucracy accountable (Histiraludin, 2004; Pratikno 2005; Suhirman, 2005 and 2009; Handayani, 2006a and 2006b; Pratikno and Lay 2010; FISIPOL UGM, 2012). Beside civil society forces, this good practice has also been made possible by the quality of leadership at the local level. This could be identified in several studies on disaster-sensitive budget allocation (Wijiyanti, 2010), gender issues, pro-poor issues (Sundari, 2005), and the openness of the local leader toward building democratic relations with civil society (Pratikno and Lay, 2010). 


\section{Democratic governance formats in local politics}

Much of the literature on Indonesian politics offers alternative models for future political development. The critical problem, it has been argued, is the lack of political representation in the democratic system. In addition, heterogeneity of local politics in Indonesia is also emerging as a new consideration for improving political processes in at the local level.

Concerning decentralisation, Academic team of Jurusan Politik \& Pemerintahan, Universitas Gadjah Mada (2010) advocated a concept of asymmetrical decentralisation. The basic argument was that the problem and capacity of regions in Indonesia was highly diverse meaning that the current symmetrical model of decentralisation was ineffective. They recommended giving specific authority to local governments based on various backgrounds and bases. This would offer a more dynamic and contextual model of decentralisation.

In its study (2010), the team recommended several determining factors for the formulation of an asymmetrical decentralisation design. The first is regional distinctiveness arising out of political factors. Through this, a given region would get recognition for its distinctive character due to its unique political-historical background in the process of its integration into the Indonesian Republic. Two regions, at least, have this characteristic - Aceh and Papua.

The second dimension of regional distinctiveness arises out of socio-cultural factors. Such factors would be acknowledged in a given region where local government institutions have existed prior to the advent of the national state. From a historical perspective, we may easily find various local government units to have existed in two forms. First, there were local government institutions in the form of volksgemeen-shcappen (community-based governance). This category included, for example, nagari (West Sumatera), desa (Java Islands), gampong (Aceh), marga (North Sumatera). The second form was local government institutions that were established out of former self-governing regions or kingdoms. The Yogyakarta Special Region would be the most tangible example of this category.

The third aspect of regional distinctiveness is based on geostrategic 
196 characteristics. A given region would be considered distinctive due to its geographical or its distinctive spatial characteristic. This classification would include regions around the national's border and regions with an archipelagic landscape.

Fourthly, distinctiveness would be applied on the basis of economic potentials and growth factors. The regions of Indonesia have different economic potentials and growth rates. Based on their economic potentials these regions could be categorised into the following three categories: natural-resource rich regions, covering forestry, minerals, to fish resources; regions as centres of trade and industry, covering either goods or services; megalopolis regions.

Fifthly, distinctiveness would be applied on the basis of the rate of development acceleration and governability capacity. Based on this factor, the diversity of the regions based on their development rate could be mapped into two simple categories: poor regions and developed regions. The indicators used here was the capacity of those regions to provide and deliver health, education, and poverty reduction.

Asymmetrical decentralisation would also be compatible with the ideas of the urgency to endorse a multicultural citizenship that would emphasis the recognition of minority communities (Moorsalim et.al., 2007; Budiman, 2007 and 2009). This would be expected to be able to form a basis for the future format of Indonesian politics.

With regard to the issues of power relations at the local level, the most critical task is to improve political representation and the capacity of society in politicising opportunity structures in democracy (Tornquist, Webster and Stokke,2009). It is believed that democracy has failed to generate popular control on public matters in the 'Global South' due to the depolitisation process, given the relatively underdeveloped nature of autonomous political relations between states and their people. Hence, there is a need to counter the problem of democracy by way of more, not less, popular influences to alter the structure of power and allow for alternative processes and opportunities for agents of change.

Alternative strategies, designed well, are necessary to ensure 
the institutionalisation of democratic popular representation. Such strategies should embody three vital aspects of democratic popular representation: popular capacity building; popular organisation building; a government prepared to commit itself to the facilitation of popular representation.

\section{Conclusive remarks}

Various literatures has identified and mapped out the process of decentralisation and regional autonomy in Indonesia for more than decade. Those studies not only presented rich and good descriptions of political realities affected by the process of decentralisation at local level but also used a mixture of approaches and methods. In other words, no single reality can manifest the dynamic of local politics and no single approach can portray the process. This paradox has coloured the process.

Local politics emerged and became prominent in Indonesian politics following the process of decentralisation and regional autonomy. The crisis of state capacity after the Asian crisis in the late 1990s and rise of political demands for getting more autonomy for local political actors and resource-rich regions put pressure on the national government to endorse more decentralised political system. Political devolution is the only way that national government can take in order to hinder the balkanisation of Indonesia.

Consequently, local politics became the new arena of contestation and competition. In this new arena, the old power blocks try to persist their power by transforming and adapting their strategies in competition with the new one. Furthermore, the political boundaries between the society, state and market remain blurred. Informality and formality seem like two sides of one coin.

The good news is, in this new political arena, the electoral process and management and thus, electoral democracy, have been improved. Improved political participation from grass root has been facilitated through various formal channels and representations. Many local governments have succeeded to improve the capacity of public service delivery and social welfare. 
The bad news is that oligarchy and patrimonial culture are still there. Political institutions have changed and transformed into democratic institutions but the way to manage power relations and the political process is persistently the same.

This prominent political manifestation in local politics expresses the paradox. On the one hand, it demonstrates the presence of ethnos rather than demos politics. The absence of citizenship has been proven by the rise of ethnic politics, the revival of the adat and religious politics in many regions in Indonesia. On the other hand, it also shows the new political manifestation since many local political leaders who are exercising their power in local governance have committed to institutionalise the mixture of innovation for better public services and social welfare.

Last but not least, the critical point that we need to explore in the following studies on local politics is the problem of political representation in public affairs. The absence of democratic politics in new an\& formal democratic institutions is opening the new question about popular representation. Thue citizenship studies and the political linkages should be the new area of studies that we need to explore in studies of Indonesian local politics. 


\section{Bibliography}

Adiyoga, I Dewa Bagus Made (2003) 'Satu Bali: Upaya Mempertahankan Bali sebagai Satu Kesatuan Entitas Sosial Budaya' in Nico L. Kana, et.al (ed.) Pluralitas Dalam Perspektif Lokal Dinamika Politik Lokal di Indonesia. Salatiga: Percik.

Alqadrie, Syarief Ibrahim (2008) 'Pemekaran Wilayah: Masalah dan Implementasinya Dalam Pembangunan Daerah di Kalimantan Barat' in Ning Retnaningsih, et.al (ed.), Dinamika Politik Lokal di Indonesia: Penataan Daerah (Territorial Reform) dan Dinamikannya. Salatiga: Percik.

Amril (2002) 'Kembali ke Sistem Pemerintahan Nagari di Kabupaten Solok' in Nico L. Kana, Pradjarta Ds and Kutut Suwondo (eds.), Politik Pemberdayaan Dinamika Politik Lokal di Indonesia. Salatiga: Percik.

Antlov, Hans (2009) 'Desentralisasi Layanan Publik bagi Masyarakat Miskin', in Darmawan Tribowo \& Nur Iman Subono (eds.) Meretas Arah Kebijakan Sosial Baru di Indonesia: Lebih dari Sekedar Pengurangan Kemiskinan. Jakarta: PRAKARSA-LP3ES. Aragon, Lorraine V. (2007) "Elite Competition in Central Sulawesi" in Henk Schulte Norholt, Gerry Van Klinken, and Ireen KarangHoogenboom (eds.). Renegotiating Boundaries: Local Politics in Post Soeharto Indonesia. Leiden: KITLV Press.

Asgart, Sofian M. (2003) 'Milisi Sipil Ancaman Demokrasi dan Pruralitas: Fenomena GPK di Yogyakarta' in Nico L. Kana, et.al (ed.) Pluralitas Dalam Perspektif Lokal Dinamika Politik Lokal di Indonesia. Salatiga: Percik.

Aspinall, Edward \& Gerry Van Klinken (eds) (2011) the State and Illegality in Indonesia, Leiden: KITLV Press.

Bandiyah (2008) Evolusi Jawara di Banten: Studi Evolusi dari Bandit Menjadi Pejabat. Yogyakarta: Master thesis at Graduate Program of Political Science Gadjah Mada University.

Basyar, Hamdan, et.al (eds.) (2008), Aceh Baru: Tantangan Perdamaian dan Reintegrasi, Jakarta: P2P-LIPI.

Bertrand, Jacques (2004), Nationalism and Ethnic Conflict in Indonesia, Cambridge: Cambridge University Press.

Blane D. Lewis (2001), “The New Indonesian Equalisation Transfer”, 
Bulletin of Indonesian Economics Studies, Vol. 37 No.3 December 2001. Canberra: ANU-CSIS.

Budiman, Hikmat (ed.) (2007), Hak Minoritas: Dilema Multikulturalisme di Indonesia, Jakarta: Interseksi Foundation.

Budiman, Hikmat (ed.) (2009), Hak Minoritas: Ethnos, Demos, dan Batas-Batas Multikulturalisme, Jakarta: Interseksi Foundation.

Burns, Peter (2010) 'Adat, yang mendahului semua hukum' in Jamie S. Davidson, David Henley, Sandra Moniaga, Adat Dalam Politik Indonesia. Jakarta: Yayasan Obor Indonesia and KITLVJakarta.

Chauvel, Richard (2010), "Electoral Politics and Democratic Freedoms in Papua" in Edwards Aspinall \& Marcus Mieztner (eds.), Problems of Democratisation in Indonesia: Elections, Institutions, and Society, Singapore: Institute of Southeast Asian Studies.

Crouch, Harold (2010) Political Reform in Indonesia After Suharto, Singapore: ISEAS.

Dwipayana, A.A.G.N Ari (2004) Bangsawan dan Kuasa: Kembalinya Para Ningrat di Dua Kota. Yogyakarta: IRE Press.

Dwipayana, A.A.G.N Ari \& I Gusti Ngurah Putra (2003) "Adat, Negara dan Kapital di Bali” in Jim Schiller (ed.). Jalan Terjal Reformasi Lokal: Dinamika Politik di Indonesia. Yogyakarta: Program Pascasarjana Politik Lokal dan Otonomi Daerah Universitas Gadjah Mada.

Dwiyanto, Agus, etc. (2003) Teladan \& Pantangan dalam Penyelenggaraan Pemerintahan dan Otonomi Daerah. Yogyakarta: Pusat Studi Kependudukan \& Kebijakan UGM.

Edward Aspinall \& Greg Fealy (2003) 'Introduction:Decentralisation, Democratisation and the Rise of Local'in Edward Aspinall \& Greg Fealy (eds.), Local Power and Politics in Indonesia: Decentralisation \& Democratisation, Singapore: Institute of Southeast Asian Studies.

Eko, Sutoro (2005) Menggantang Asap? Kritik dan Refleksi Atas Gerakan Kembalik Nagari. Yogyakarta: IRE.

Eko, Sutoro (2009) "Daerah Budiman: Prakarsa dan Inovasi Lokal Membangun Kesejahteraan”, in Darmawan Tribowo \& Nur 
Iman Subono (eds.) Meretas Arah Kebijakan Sosial Baru di

Indonesia: Lebih dari Sekedar Pengurangan Kemiskinan. Jakarta: PRAKARSA-LP3ES. Erb, Maribeth \& Priyambudi Sulistyanto (eds.) (2009), Deepening Democracy in Indonesia? Direct election for Local Leaders (PILKADA), Singapore: Institute of Southeast Asian Studies.

FISIPOL UGM (2012) Kajian Implementasi UUNO. 14 tahun 2008 dalam Tata Kelola Pemerintahan Daerah. Yogyakarta: FISIPOL UGM-TIFA

Gaffar, Afan (2000)“ Kebijakan Otonomi Daerah dan Implikasinya Terhadap Penyelenggaraan Pemerintahan di Masa Mendatang”, Jurnal Wacana, No. V., Yogyakarta: INSIST Press.

Gaffar, Afan, et.al (2002) Otonomi Daerah dalam Negara Kesatuan, Yogyakarta: Pustaka Pelajar dan PUSKAP.

Gunawan, Jamil, Sutoro Eko, Anto B dan Bambang Purwanto (eds.) (2004) Desentralisasi, Globalisasi, dan Demokrasi Lokal. Jakarta: Yayasan Obor Indonesia.

Hadi, Syamsul et.al (2006) Disintegrasi Pasca Orde Baru Negara, Konflik Lokal dan Dinamika Internasional. Jakarta: Yayasan Obor Indonesia.

Hadiz, Vedi R. (2010) Localizing Power in Post -Authoritarian Indonesia: A Southeast Asia Perspective, Stanford California: Stanford University Press

Handayani, Suci (2006a) Pelibatan Masyrakat Marginal dalam Perencanaan dan Penganggaran Partisipatif: Sebuah Pengalaman di Kota Solo. Solo: Kompip

Handayani, Suci (2006b) Merajut Harapan Menuju Perubahan. Solo: Kompip.

Hanif, Hasrul (2009), Governing Through New Social Myth: Discursive Formation of Local Welfarism in Decentralised Indonesia, Master thesis at Graduate Program of Political Science Gadjah Mada University.

Hanif, Hasrul \& Oktafiani Catur P (2007) Dilema Formasi Politik Teritori Baru: Pemekaran Daerah, Politik Identitas dan Integrasi Nasional. Paper presented at National Seminar XXI AIPI (ASOSIASI ILMU POLITIK INDONESIA), Manado, and 
august $14-152007$.

Harriss, John, Kristian Stokke, Olle Tornquist (2004), “Introduction: The New Local Politics of Democratisation" in Harriss, John, Kristian Stokke, Olle Tornquist (eds.), Politicising Democracy: The New Local Politics of Democratisation, New York: Palgrave Macmillian.

Henley, David \& Jamie S. Davidson (2007) "Radical ConservatismThe Protean Politics of Adat" in David Henley \& Jamie S. Davidson (eds.), the Revival of Tradition in Indonesian Politics: the deployment of Adat from colonialism to Indigenism, London: Routledge.

Hidayat, Syarief (2002) 'Ketimpangan Ekonomi dan Fenomena Rent-Seeking di Daerah-Kasus Tata Niaga Kayu Cendana di NTT' in Nico L. Kana, Pradjarta Ds and Kutut Suwondo (eds.) Politik Pemberdayaan Dinamika Politik Lokal di Indonesia. Salatiga: Percik.

Hidayat, Syarif (2007) “'Shadow State'? Bussines and Politics in the Provience of Banten” in Henk Schulte Norholt, Gerry Van Klinken, and Ireen Karang-Hoogenboom (eds.).Renegotiating Boundaries: Local Politics in Post Soeharto Indonesia. Leiden: KITLV Press.

Histiraludin, Muhammad (2004) Bergumul Bersama Masyrakat Berbagi Cerita Proses Perencanaan Partisipatif di Kota Solo. Solo: IPGI.

Hotman, Bert, Kai Kaiser, and Gunther G. Schulze (2009)

'Corruption and Decentralization' in Coen J.G, Holtzappel \& Martin Ramsted (eds).Decentralization and Regional Autonomy in Indonesia: Implementation and Challenges. Singapore: International Institute for Asian Studies.

Husain, M. Najib and Syahril Ramadhan (2008) 'Gejolak Politik dalam Penataan Daerah Kab Buton Utara Pasca Pemekaran' in Ning Retnaningsih, et.al, (eds.) Dinamika Politik Lokal di Indonesia: Penataan Daerah (Territorial Reform) dan Dinamikannya. Salatiga: Percik.

Husna, Lilis Nurul \& Arie Sujito (2009) 'Strategi CSO Working Group dan Penguatan Panitia Anggaran' in Abdul Waidl, 
Yuna Farhan \& Diding Sakri (eds.), Anggaran Pro Kaum

Miskin: Sebuah Upaya Menyejahterakan Masyarakat, Jakarta: PRAKARSA \& LP3ES.

JPIP (2006) Otonomi Daerah \& Otonomi Award Dua Propinsi. Surabaya: Jawa Pos Pro-otonomi Institute.

JPP UGM (2010) Fisibilitas Kajian Pemekaran Kota Sofifi, Propinsi Maluku Utara. Unpublished research report. Yogyakarta: POLGOV JPP UGM.

JPP UGM (2010), Desentralisasi Asimetris di Indonesia: Praktek dan Proyeksi, JPP UGM-TIFA.

Kaho, Josef Riwu (1982) Analisa Hubungan Pemerintah Pusat dan Daerah di Indonesia. Jakarta: Bina Aksara.

Kaho, Josef Riwu (1988) Prospek Otonomi Daerah Di Negara Republik Indonesia: Indentifikasi Beberapa Faktor yang Mempengaruhi Penyelenggaraannya. Jakarta: Rajawali Press.

Karim, Abdul Gaffar (ed.) (2003) Kompleksitas Persoalan Otonomi Daerah di Indonesia. Yogyakarta: Pustaka Pelajar \& JIP UGM.

Karomba, Sem, (2004) Papua Menggugat: Politik Otonomisasi NKRI di Papua Barat! Bagian I: Papua Mencatat. Yogyakarta: Galang Press dan WatchPAPUA.

Klinken, Gerry Van (2010) 'Kembalinya para sultan: Pentas gerakan komunitarian dalam politik lokal' in Jamie S. Davidson, David Henley, Sandra Moniaga, Adat Dalam Politik Indonesia. Jakarta: Yayasan Obor Indonesia and KITLV.

Kocu, Edward M. (2007) Prisoner's Dilemma (Studi tentang Rivalitas Etnis terhadap Perilaku Memilih dalam Pilkada Sorong Selatan Papua Barat). Yogyakarta: Master thesis at Graduate Program of Political Science Gadjah Mada University.

Lay, Cornelis (2000) "Pemberdayaan Lembaga-Lembaga Legislatif Daerah dalam rangka Otonomi Daerah", Jurnal Wacana, Edisi V tahun 2000. Yogyakarta: INSIST Press.

Lay, Cornelis (2003) "Otonomi Daerah dan Keindonesiaan", in Abdul Gaffar Karim (ed.), Kompleksitas Persoalan Otonomi Daerah di Indonesia, Yogyakarta: Pustaka Pelajar \& JIP UGM.

Lay, Cornelis (2010) Melawan Negara: PDI 1973-1986, Yogyakarta: POLGOV JPP FISIPOL UGM. 
204 Malley, Micahel S, (2003) "New Rules, Old Structures, and the Limits of Democratic Decentralisation," in ed. Edward Aspinall and Greg Fealy (eds.), Local Power and Politics in Indonesia: Decentralisation and Democratisation. Singapore: Institute of Southeast Asian Studies.

Maunati, Yekti (2004) Identitas Dayak Komodifikasi dan Politik Kebudayaan. Yogyakarta: LKiS.

Muhammad, Rusjdi Ali (2003) Revitalisasi Syariat Islam di Aceh Problem, Solusi dan Implementasi Munuju Hukum Islam di Nanggroe Aceh Darussalam. Jakarta: Logos.

Musa, Hardi (2008) Strategi Fagogoru Memperjuangkan Terbentuknya Kabupaten Halmahera Timur.Yogyakarta: Master thesis at Graduate Program of Political Science Gadjah Mada University. Noorsalim, Mashudi, et.al (eds.) (2009), Hak Minoritas: Multikulturalisme \& Dilema Negara Bangsa, Jakarta: Interseksi Foundation.

Nordholt, Henk Schulte (2004), Decentralisation in Indonesia: Less State, More Democracy?" in Harriss, John, Kristian Stokke, Olle Tornquist (eds.), Politicising Democracy: The New Local Politics of Democratisation. New York: Palgrave Macmillian.

Pamungkas, Cahyo (2008) 'Politik Integrasi dan Konflik Elit Lokal, Dalam Pemekaran: Studi Kasus Pembentukan Provinsi Irian Jaya Barat' in Ning Retnaningsih, et.al (ed.), Dinamika Politik Lokal di Indonesia: Penataan Daerah (Territorial Reform) dan Dinamikanya. Salatiga: Percik.

Pamungkas, Sigit, Hasrul Hanif \& Erwin Endaryanta (2010), "Aceh: Perdamaian yang Terancam" in Pratikno, et.al (eds.) Desentralisasi Asimetris di Indonesia: Praktek dan Proyeksi. Yogyakarta: POLGOV JPP UGM-Yayasan Tifa.

Praing, Darius U. D. A (2009) Bertahannya Kekuasaan Maramba Umalulu: Studi tentang Survivalitas Elit Tradisional Sumba di Era Perubahan. Yogyakarta: Graduate Thesis PLOD UGM.

Prasetyo, Stanley Adi \& Teresa Birks (2010) "Background and Political Situation in Aceh" in Olle Tornquist, Stanley Adi Prasetyo \& Teresa Birks (eds.) Aceh: the Role of Democracy for Peace and Reconstruction. Yogyakarta: PCD Press. 
Pratikno (2002) Initiating Citizen Participation in Local Policy 205 Making in Indonesia: The Case of Surakarta Municipality in the Post Authoritarian Regime, 1999-2002, ADB paper series.

Pratikno (2003) "Desentralisasi: Pilihan yang tidak Pernah Final", in Jim Schillers (ed.), Jalan Terjal Reformasi Lokal: Dinamika Politik di Indonesia. Yogyakarta: PLOD UGM.

Pratikno (2005), "Exercising Fredom: Local Autonomy and Democracy in Indonesia, 1991-2001, in Maribeth Erb, Priyambudhi Sulistyanto \& Carole Faucher (eds.), Regionalism in Post Soeharto Indonesia, Routledge Curzon.

Pratikno (ed.) (2007) Kerjasama Antar Daerah: Kompleksitas dan Tawaran Format Kelembagaan. Yogyakarta: JIP FISIPOL UGMPLOD FISIPOL UGM.

Priyono, A.E \& Nur Imam Subono (2007) “ Demokrasi Oligarkis: Kolonisasi Instrumen Demokrasi oleh Elit Dominan" in AE Priyono, Willy Purna Samadhi \& Olle Tornquist (eds.), Menjadikan Demokrasi Bermakna: Masalah \& Pilihan di Indonesia. Jakarta: DEMOS.

Rasyid, M.Ryaas (2003), "Regional Autonomy and Local Politics in Indonesia" in ed. Edward Aspinall and Greg Fealy (eds.), Local Power and Politics in Indonesia: Decentralisation and Democratisation, Singapore: Institute of Southeast Asian Studies. Reid, Anthony (2006), Veranda of Violence: the Background to the Aceh Problem. Singapore: NUS Press.

Rohdewohld, Rainer (2003) "Decentralisation and the Indonesian Bureaucracy: Major Changes and Minor Impact? InEdward Aspinall and Greg Fealy (eds.), Local Power and Politics in Indonesia: Decentralisation and Democratisation. Singapore: Institute of Southeast Asian Studies.

Roth, Dik (2007) "Many Governors, No Province: the Struggle for a Province in the Luwu-Tana Toraja area in South Sulawesi" in Henk Schulte Norholt, Gerry Van Klinken, and Ireen KarangHoogenboom (eds.). Renegotiating Boundaries: Local Politics in Post Soeharto Indonesia. Leiden: KITLV Press.

Rozi, Syafuan (2009) "Nasionalisme, Demokratisasi, dan Sentimen Primordialisme di Indonesia: Problematika Identitas Keetnisan 
Versus Keindonesiaan Pada Studi Kasus Aceh, Papua, Bali, dan Riau”, Jurnal Penelitian Politik, Volume 6 No. 1, 2009. Jakarta: LIPI

Said, M. Mas'ud (2005) Arah Baru Otonomi Daerah di Indonesia. Malang: UMM Press.

Santoso, Purwo \& Adam Tirta (2003) "Reformasi Politik Lokal dalam Ketegaran Struktur Elitis: Memahami Ketegaran GOLKAR di Takalar Sulawesi Selatan” in Jim Schiller (ed.). Jalan Terjal Reformasi Lokal: Dinamika Politik di Indonesia. Yogyakarta: Program Pascasarjana Politik Lokal dan Otonomi Daerah Universitas Gadjah Mada.

Sarumpaet, Budi Ali Mukmin (2009) Politik Etnis Tionghoa Kota Medan. Yogyakarta: Master thesis at Graduate Program of Political Science Gadjah Mada University..

Savirani, Amalinda (2004) Local Strongman in New Regional Politics in Indonesia.Amsterdam: Master Thesis, International School of Humanities and Social Sciences, University of Amsterdam.

Schmidt, Adam (2010) "Indonesia'a 2009 Elections: Performance Challenges and Negative Precendents" in Edwards Aspinall \& Marcus Mieztner (eds.), Problems of Democratisation in Indonesia: Elections, Institutions, and Society, Singapore: Institute of Southeast Asian Studies.

Sidel, John T (2004) 'Bossism and Democracy in the Philippines, Thailand, and Indonesia: Towards an Alternative Framework for the Study of 'Local Strongmen' “in Harriss, John, Kristian Stokke, Olle Törnquist (eds.), Politicising Democracy: The New Local Politics of Democratisation. New York: Palgrave Macmillian. Silver, Christopher, Iwan J. Azis \& Larry Schroeder (2001), "Intergovernmental Transfers and Decentralisation in Indonesia", Bulletin of Indonesian Economics Studies, Vol. 37 No.3 December 2001. Canberra: ANU-CSIS.

Steijlen, Fridus (2004) 'Penanda Lama untuk Ideologi Baru RMS dan Konflik Maluku' in Jim Schiller (ed.).Jalan Terjal Reformasi Lokal: Dinamika Politik di Indonesia. Yogyakarta: Program Pascasarjana Politik Lokal dan Otonomi Daerah Universitas Gadjah Mada. 
Suhirman (2005) 'Kerangka Hukum Perencanaan dan Penganggran

Daerah di Indonesia: Tantangan untuk Partisipasi Publik' in Sugeng Bahagijo and Rusdi Tagaroa (ed.), Orde Partisipasi Bunga Rampai Partipasi dan Politik Anggaran. Jakarta: Perkumpulan Prakarsa.

Suhirman (ed.) (2009) Partisipasi, Reformasi Kelembagaan, dan Alokasi Anggaran: Pembelajaran dari Lima Daerah. Bandung: FPPM.

Sukma, Rizal (2010) 'Indonesia's 2009 Elections: Defective System, Resilient Democracy" in Edwards Aspinall \& Marcus Mieztner (eds.), Problems of Democratisation in Indonesia: Elections, Institutions, and Society, Singapore: Institute of Southeast Asian Studies.

Sumanto, Hetifah Sj. (2009) Inovasi, Partisipasi, dan Good Governance 20 Prakarsa Inovatif dan Partisipatif di Indonesia. Jakarta: Yayasan Obor Indonesia.

Sumarty, Betty (2007) Revitalisasi Peran Ninik Mamak dalam Pemerintahan Nagari. Yogyakarta: JIP UGM

Sundari, Eva K. (2005) 'Mengapa Harus Gender Responsive Budget?' in Sugeng Bahagijo and Rusdi Tagaroa (eds.), Orde Partisipasi Bunga Rampai Partipasi dan Politik Anggaran. Jakarta: Perkumpulan Prakarsa.

Supeno, Hadi (2009) Korupsi di Daerah: Kesaksian, Pengalaman dan Pengakuan. Yogyakarta: Kreasi Total Media

Tamrin, An'am A \& V. Sri Wijiyati (eds.) (2006) Menjaring Uang Rakyat: Ragam Advokasi Anggaran di Indonesia. Yogyakarta: IDEA-TIFA.

The Asia Foundation (2004) Indonesia Rapid Decentralisation Appraisal (IRDA) V. Jakarta: the Asia Foundation.

Tirtosudarmo, Riwanto (2007) Mencari Indonesia Demografi-Politik Pasca Soeharto. Jakarta: Yayasan Obor Indonesia and LIPI

Törnquist, Olle (2009) 'Introduction: The ProblemIs Representation! Towardsan Analytical Framework' in Olle Törnquist, Neil Webster, and Kristian Stokke (eds.), Rethinking Popular Representation. New York: Palgrave-Macmillian.

Tornquist, Olle, Stanley Adi Prasetyo, \& Teresa Birks (eds.) (2011), 
Aceh: the Role of Democracy for Peace and Recontruction, Yogyakarta: PCD Press.

Uhlin, Anders (1997) Indonesia and the "Third Wave of Democratization": The Indonesian Pro-Democracy Movement in a Changing Worlds, London: Curzon Press.

Umasugi, Achdjam Syahfan (2009) Instumentasi Etnis dalam Pilkada Langsung.Studi tentang Peran Etnis dalam Kontestasi Politik di Pilkada Langsung Kabupaten Buru Provinsi Maluku Tahun 2006.Graduate Thesis PLOD UGM.

Vel, Jacqueline (2007) "Campaigning for a New District in West Sumba” in Henk Schulte Norholt, Gerry Van Klinken, and Ireen Karang-Hoogenboom (eds.).Renegotiating Boundaries: Local Politics in Post Soeharto Indonesia. Leiden: KITLV Press.

Wanimbo, Damianus (2003) 'Keadilan=Ketidakadilan Bagi Papua' in Jim Schiller (ed). Jalan Terjal Reformasi Lokal: Dinamika Politik di Indonesia. Yogyakarta: Program Pascasarjana Politik Lokal dan Otonomi Daerah Universitas Gadjah Mada.

Wibisono, Yusuf (2003) 'Desentralisasi Fiskal di Indonesia: Pengalaman Terkini dan Prospek ke Depan’ in Indra J. Piliang, Dendi Ramdani, and Agung Pribadi (eds.), Otonomi Daerah Evaluasi dan Proyeksi. Jakarta: Yayasan Harkat Bangsa.

Widianingsih, Ida (2006) "Local Governance, Decentralization, and Participatory Planning in Indonesia: Seeking a New Path to a Harmonious Society" in Raza Ahmad (ed.). The Role of Public Administration in Building a Harmonious Society. Selected Proceedings from the Annual Conference of the Network of Asia-Pacific Schools and Institutes of Public Administration and Governance (NAPSIPAG) Beijing, People's Republic of China, 5-7 December 2005.

Widiasari, Nurmalia Ika (2008) 'Urgensi Otonomi Khsusu di Nangroe Aceh Darussalam' in Ning Retnaningsih, et.al (ed.), Dinamika Politik Lokal di Indonesia: Penataan Daerah (Territorial Reform) dan Dinamikannya. Salatiga: Percik.

Wignjosoebroto, Soetandyo (2005), Desentralisasi Dalam Tata Pemerintahan Kolonial Hindia Belanda: Kebijakan dan Upaya Sepanjang Babak Akhir Kekuasaan Kolonial di Indonesia (1900 - 
1940). Yogyakarta: Bayumedia.

Wijiyanti, Valentina Sri, (eds.) (2010) Meredam Resiko Bencana:Upaya Integrasi PRB Dalam Perencanaan dan Penggaran Daerah. Yogykarta: IDEA Jogja.

Wilson, Ian (2010) 'The Rise and Fall of Political Gangsters in Indonesian Democracy' In Edward Aspinall and Marcus Mietzner (Eds.), Problem of Democratisation in Indonesia, Election, Institution and Society. Singapore: ISEAS Publishing.

Windia, Wayan P. (2008) Bali Mawacara Gagasan Satu Hukum Adat (Awig-awig) dan Pemerintahan di Bali.Denpasar: Pusat Penelitian Hukum Adat Universitas Udayana.

World Bank-INDOPOV (2006).Inovasi Pelayanan Pro-Miskin: Sembilan Studi Kasus di Indonesia. Jakarta: World BankINDOPOV. 